\title{
Famílias de elite: transformação da riqueza e alianças matrimoniais. Belém 1870-1920
}

\author{
Cristina Donza Cancela
}

O período que compreendeu os anos de 1870 a 1920 foi marcado por inúmeras mudanças na capital paraense. O auge da exploração da borracha, que se convencionou delimitar no ano de 1876, possibilitou o aumento da renda da província, o surgimento e incremento de bancos e seguradoras, a ampliação do setor de serviços e de transportes, o crescimento populacional intensificado. Nesse cenário de maior liquidez econômica e circulação de pessoas, Belém transformou-se no maior porto de escoação da goma elástica da região amazônica. A propósito de algumas das transformações acima indicadas já se fazerem presentes antes da década de 70, é no final do século XIX e início do XX que elas se intensificaram.

Seguindo estas mudanças, as relaçôes sociais foram redefinidas a partir da formação, consolidação e rearranjo dos grupos sociais. Famílias de proprietários de terra e gado, enraizados na província ainda no período colonial, tiveram que flexibilizar suas atividades para fazer frente às novas demandas do mercado e aos indivíduos recém-chegados, sem tradição de nome, mas com fortunas centradas no negócio da borracha, ou às atividades incrementadas a partir da expansão gomífera. Com o estabelecimento de novos signos de riqueza, as famílias da elite local, cujo patrimônio e prestígio estavam pautados preferencialmente na propriedade de engenhos, criação de gado, ocupação de cargos administrativos, funções militares e, por vezes, firmas comerciais, tiveram de restabelecer seus investimentos em novas bases, iniciando e/ou associando-se aos novos negócios e aos comerciantes estrangeiros e nacionais.

De que forma essas mudanças econômicas podem ser percebidas na configuração da riqueza das famílias de elite? Até que ponto a formação de um grupo de comerciantes, constituído preferencialmente por pessoas de fora do Estado, alterou o padrão de alianças matrimoniais das famílias proprietárias locais? Essas são algumas das principais questóes que me proponho a discutir neste trabalho.

\section{Uma família, uma trajetória patrimonial}

Para se entender melhor o significado desse novo contexto econômico na re-figuração da riqueza das famílias proprietárias tradicionais, destaco a trajetória dos Pombo, cuja história patrimonial pode ser construída a partir dos inventários de várias gerações de seus membros.

Advinda do Reino da Galizia, essa família de fidalgos, chegou ao Grão-Pará na segunda metade do século XVIII. Um dos seus primeiros nomes, Joaquim Clemente da Silva Pombo, foi ouvidor da Comarca do Pará, entre 1810-1817. Era pecuarista e proprietário de terras das Ilhas Mexianas, localizadas no Arquipélago do Marajó. Estas terras foram posteriormente herdadas por seu filho, Ambrósio, agraciado com o título de Barão de Jaguarari, em 1830. Esta alcunha tem origem no engenho homônimo de propriedade da família, localizado nas proximidades de Belém, mais especificamente no baixo Tocantins. ${ }^{1}$

A base de sua fortuna estava centrada na propriedade de terras, engenhos e fazendas de criação de gado com uso da mão de obra escrava, como era comum às famílias proprietárias da primeira metade do século XIX. ${ }^{2}$

No entanto, este quadro começa a ser alterado a partir da segunda metade daquele século. Descendente da família Pombo, João Florêncio Henrique da Silva Pombo herda as terras das Ilhas Mexianas e, em seu inventário no ano de 1865, juntamente com cerca de 30 escravos, vários animais, casas e terrenos em Belém, declara a presença de seringais em seus domínios, os quais correspondiam a quase $9 \%$ do valor total de seus bens. ${ }^{3}$

Quando da morte de sua mulher, Maria Emilia de Mancada Pombo, 13 (treze) anos depois, em 1888, os seringais já correspondiam a $18 \%$ dos bens de herança, tendo desta forma multiplicado o va- 
lor em relação às demais posses da família. No inventário do filho do casal, em 1893, o tenente-coronel Ambrósio Henriques da Silva Pombo, o valor das terras da Ilha Mexiana contendo as estradas de seringueiras equivalia a $40 \%$ do patrimônio inventariado. Poderia-se pensar que a família havia perdido seus bens, daí o aumento do valor dos seringais no montante do legado das diversas geraçóes. Entretanto, não é isso que se deduz da análise dos inventários. As antigas casas, terrenos e açôes não só continuavam fazendo parte dos bens familiares, como a elas foram somados novos imóveis e renda, do que se depreende que não foram estes bens que perderam seu valor agregado, mas a presença e a extração de seringais nas fazendas da Ilha Mexiana que elevaram o preço e a rentabilidade dessas terras. ${ }^{4}$

A trajetória dos legados aqui pontuada demonstra como, gradativamente, a borracha vai ganhando espaço nos negócios da família Pombo, que, concomitantemente a esta atividade, continuava investindo na criação de gado como tradicionalmente o fazia, sendo ainda uma referência nesse negócio na região. Basta citar que, em 1894, dentre os 05 (cinco) fazendeiros que receberam prêmios do governo estadual por terem importado gado da Europa e América do Norte para incrementar a indústria pastoril no Pará, estava o nome de Floripes Chermont de Miranda Pombo, viúva do tenente-coronel Ambrósio Henriques da Silva Pombo, acima referido. ${ }^{5}$

O exemplo dos Pombo evidencia o crescimento do valor agregado dos seringais no patrimônio das famílias da elite local, particularmente a partir da década de 1870, quando a borracha cresce em prestígio e legitimidade em função do aumento do volume de negócios e da entrada de importantes firmas estrangeiras no seu comércio.

O mesmo processo vai ser encontrado em meio a outras famílias igualmente tradicionais como os Chermont, Bezerra, Lobato, Miranda, Pombo e Monard. Todas elas proprietárias de grandes áreas de criação de gado, engenhos de açúcar e olarias, nas diversas localidades da Ilha do Marajó, em Belém e seus arredores. A ocupação destas terras remonta à concessão de sesmarias por parte da Coroa portuguesa à época da colonização. Muitas delas pertenciam inicialmente à ordem dos jesuítas. Com a expulsão desses religiosos, as propriedades foram sequestradas e transferidas pela Coroa a particulares, tornandose a base econômica daquelas famílias. ${ }^{6}$

Pouco a pouco, esses proprietários de gado do Marajó e de engenhos de diversas regiōes paraenses vão combinar essas atividades, com a extração de seringa e a participação em firmas comerciais, disputando e/ou aliando-se aos novos comerciantes, em grande parte formados por migrantes recém-chegados à capital. Pois, como ocorreu em outras localidades brasileiras, o comércio tornou-se a atividade mais viável aos estrangeiros, uma vez que a posse da terra, para o desenvolvimento de atividades agrícolas e pastoris, estava centrada nas mãos das famílias tradicionais.

\section{Signos de riqueza familiar: permanências e mudanças}

A questão que agora se coloca é de que forma a expansão mercantil verificada nesse final do século XIX vai estar refletida nas mudanças do perfil da riqueza e do patrimônio das famílias da elite local, entendida aqui como o grupo de indivíduos abastados que têm privilégios, influência e poder inacessíveis aos demais membros da sociedade. ${ }^{7}$

O fim da mão-de-obra escrava, o fortalecimento do comércio e das casas de aviação, a diversificação dos bens e serviços, o incremento da instituição bancária e das sociedades por ações, atualizam mudanças importantes na sociedade belenense no final do século XIX.

Até que ponto estas mudanças se refletiram na valorização de alguns bens em detrimento de outros e a ascensão de novos tipos de investimento, com a consequente recriação dos signos de valor, prestígio e poder?

É um pouco do movimento desses patrimônios que passo a discutir, tomando como recorte o perfil das fortunas por década.

Inicio destacando que, dentre os principais bens contidos nos legados, ao longo das décadas de 1870 a 1880, ganhavam destaque: os escravos, as terras com as benfeitorias nelas realizadas e o gado. 
Em relação aos escravos, vale dizer que um cativo entre 17 (dezessete) e 30 (trinta) anos de idade, com boa saúde e uma profissão, comumente era avaliado em algo em torno de um conto de réis (89£), na década de 1870 .

No conjunto de 101 (cento e hum) inventários pesquisados, relativos à década de 1870, em 54\% deles, portanto um pouco mais da metade, havia o arrolamento de escravos entre os bens descritos, perfazendo um total de 373 indivíduos.

A maior parte desses escravos pertencia a cerca de cinco grandes proprietários que, em sua maioria, eram donos de engenhos. Dentre eles encontrava-se o coronel Antonio Francisco Corrêa Caripuna, natural da então Villa de Igarapé-Miry. Seu engenho, localizado na mesma vila, possuía maquinário e utensílios para funcionamento de olaria e alambique. Os 47 (quarenta e sete) escravos arrolados em seu inventário equivaliam a um total de 36\% de seus bens. Esse valor era apenas 4\% menor do que a avaliação feita dos dois engenhos de sua propriedade, aí somadas as maquinarias, os utensílios e as demais benfeitorias como trapiches, casas e pontes. De uma maneira geral, o patrimônio destes coronéis era composto pelos escravos, engenhos e algumas sortes de terras, juntamente com casas e terrenos localizados em Belém.

Em relação aos proprietários de fazendas de gado, somavam-se aos bens acima destacados os inúmeros animais e, por vezes, barcos utilizados para o transporte dos mesmos. Quando da morte de sua mulher Maria Bárbara, em 1872, o então presidente da câmara municipal de Soure, o major da guarda nacional Francisco Xavier Pereira de Mello, possuía várias fazendas de gado naquele município, localizado na Ilha do Marajó. Faziam também parte de seu patrimônio um total de 17 (dezessete) escravos, alguns residentes nas fazendas, outros em Belém. Embora pecuaristas no Marajó, a família possuía várias casas em Belém, além de investimentos em ações da Companhia Urbana dessa cidade. ${ }^{8}$

Portanto, escravos, terras, animais e barcos para seu transporte constituíam-se nos bens mais valiosos encontrados nos legados desse decênio. É curioso como, nesses autos, ainda encontramos a descrição pormenorizada de móveis, utensílios domésticos, roupas, objetos de uso pessoal, imagens sagradas e jóias. Um costume que vai, pouco a pouco, perdendo espaço nos documentos das décadas seguintes, onde a descrição desses itens tende a desaparecer, ou ser feita de forma global, sem detalhamento, com exceção das jóias e objetos de prata e ouro.

Ao chegar à década de 1880, percebo que os signos de riqueza permaneceram os mesmos da década anterior. No entanto, alguns elementos começavam timidamente a se diferenciar. Exemplo disto pode ser encontrado no fato de que a presença de escravos arrolados nos inventários deste período, embora ainda ocorresse, sofre um decréscimo. De certo modo, esta queda se explica pelos fatos que antecederam o fim do trabalho escravo, como o término do tráfico, as recorrentes fugas, o aumento no número de libertos e as vendas de cativos para as demais províncias brasileiras.

Com isso, os legados onde houve o arrolamento de escravos concentraram-se nos anos de 1880 e 1881, havendo uma diminuição considerável nos demais anos posteriores a essa data e anteriores a 1888, quando se tem o fim da escravidão.

E ainda, se no decênio anterior em 54\% dos legados havia referência à existência de cativos, durante a década de 1880 esse número cai para 34\%. Não apenas o número de legados contendo escravos foi reduzido, como o próprio número de cativos existentes no patrimônio também sofreu um decréscimo considerável na década de 1880 , em relação a 1870 , passando de 373 (trezentos e setenta e três) indivíduos, para 153 (cento e cinquenta e três). Por outro lado, assim como na década anterior, observouse a concentração de cativos em poder de alguns poucos proprietários. Basta destacar que cerca de $40 \%$ do total de escravos arrolados nos inventários pertenciam a cinco proprietários, de famílias distintas das anteriormente encontradas para o decênio de 1870.

Além da diminuição gradativa no número de escravos nos legados da década de 1880 uma outra mudança pôde ser encontrada neste período. O inventário de José Joaquim Alves Picanço é bastante exemplar no que diz respeito a essa questão. Proprietário de um plantel significativo de escravos e de um engenho de moer cana, onde havia maquinário de olaria, serraria e marcenaria, declarou em suas terras 
a existência de estradas de seringais. ${ }^{9}$ Pouco a pouco, as sortes de terras contendo seringas começam a ser identificadas nos arrolamentos dos inventários.

Chegando à década de 1890, as mudanças no perfil do patrimônio finalmente se acentuam. Estradas de seringais, casas de aviaçãa ${ }^{10}$ e firmas comerciais passam a constar cada vez com mais frequencia nos legados, tendência essa que persistirá até a década de 1920. Junte-se a eles a compra de ações e a aquisição de imóveis urbanos, que começam a constituir-se nas formas mais comuns de emprego de capital.

No que diz respeito ao mercado de açôes, vê-se seu crescimento em Belém a partir da ampliação das instituições fornecedoras de crédito para investimento. Na década de 80, por exemplo, tem-se a fundação, na capital, do Banco do Pará, Banco de Belém e o fortalecimento do Banco do Comércio. Nessa mesma década, implementam-se sete novas firmas seguradoras. A renda fundiária passa a competir com os títulos financeiros.

As açôes de banco, juntamente com as das companhias de seguro e empresas prestadoras de serviços, eram as preferencialmente compradas. $\mathrm{O}$ investimento em ações ocorrido com a expansão da borracha chegou a render até $31 \%$ sobre o valor inicial empregado. ${ }^{11}$

Esse investimento chega a duplicar na década de 1900, quando comparado ao de 1870. Mas quem eram as pessoas que ingressam nesse novo tipo de investimento? Figuravam nesse grupo preferencialmente, donos de seringais, proprietários de firmas de aviamento, donos de indústria, donos de fazendas de criação de gado e proprietários de engenho. Entretanto, a despeito da grande quantidade dessas pessoas possuírem legados volumosos, encontraram-se 32 (trinta e dois) inventários de pessoas que possuíam pequenos valores a serem partilhados, que também fizeram algum investimento na compra de ações. Nesse grupo listavam-se, principalmente, militares, funcionários públicos, profissionais liberais e proprietários de pequenas firmas comerciais.

O reflexo da influência dessas novas formas de investimento no perfil e volume dos bens e dos signos de riqueza das pessoas à época pode também ser observado no item seguro de vida. Entre as décadas de 1870 e 1880, esse investimento não apareceu na partilha dos 213 (duzentos e treze) inventários levantados. Entretanto, ele estava presente em 4,5\%, dos 222 (duzentos e vinte e dois) inventários arrolados para a década de 1890 . Nos anos subsequentes, esse percentual vai ser multiplicado. Assim, nas décadas de 1900 e 1910, onde temos um total de 507 (quinhentos e sete) inventários, esse número oscila entre $9,5 \%$ e $8,5 \%$, respectivamente.

Juntamente com o investimento em ações e seguros de vida, a compra de imóveis em áreas urbanas centrais e da periferia da cidade cresce no patrimônio das famílias, sendo este um dos investimentos mais requisitados pela elite local. Era comum a pessoa ser proprietária de várias casas e terrenos de diferentes dimensões e qualidade, reiterando a ideia de que a compra desses imóveis era realizada para efeito de investimento, servindo como fonte de renda a partir da cobrança de aluguéis. Em uma cidade que crescia com a intensa migração não é de se estranhar o valor dado a este tipo de investimento, tendo em conta a grande procura por casas e prédios.

Um dos fatos que caracteriza a compra de bens de raiz, para fins de investimento imobiliário, era a compra destes imóveis em áreas distantes dos bairros mais tradicionais de Belém. Ou ainda, em áreas recém-ocupadas, como as ruas do Marco, do Umarizal, do Jurunas e da rua grande da Pedreira. Não era incomum nos inventários, encontrar arroladas várias casas térreas de porta e janela, nessas áreas de expansão da cidade.

Essa situação pôde ser verificada no inventário do médico José da Gama Malcher, que por diversas vezes foi vereador na câmara municipal de Belém, além de intendente da cidade na década de 1890 . Quando de suas funçôes administrativas, "rasgou as estradas, hoje avenidas povoadas, dos bairros Batista Campos, São João, Umarizal, até o perímetro entre Nazaré e o cemitério de Santa Izabel: prolongou a travessa São Matheus até a baía do Guajará e a Doca de Souza Franco, além do bairro do Reducto."12 Ao falecer, em 1882, José Malcher possuía dois sobrados em uma das principais artérias da cidade, a rua do Imperador, onde deveria morar com a família. A estes se somaram, diversos terrenos e casas, próximos às ruas acima descritas que José Malcher “ajudou a rasgar" na cidade. ${ }^{13}$ Muitos deles estavam localiza- 
dos no bairro denominado Jurunas, pouco urbanizado e formado por casas de madeira e palha, porém com excelente localização, pois se encontrava perto dos principais bairros e ruas da cidade, configurando-se em uma área em expansão.

Em resumo, procurei aqui destacar as transformaçōes no perfil da fortuna dos indivíduos, a partir dos legados encontrados para Belém, ao longo das décadas de 1870 a 1920. Tentei evidenciar de que forma novos tipos de bens ganharam espaço nos portfolios das famílias, refletindo a influência das transformações socioeconômicas, proporcionadas pelo comércio da borracha, na configuração das riquezas.

\section{Alianças matrimoniais na elite paraense}

Como já mencionei anteriormente, esse período marca o incremento da produção gomífera e do setor de comércio. A maior parte dos indivíduos ligados a estes investimentos comerciais possuía nacionalidade estrangeira, embora tenha encontrado alguns comerciantes nacionais vindos de outros estados brasileiros. Os portugueses, ou filhos de portugueses naturalizados, predominavam no comércio local, em particular nas casas de aviação. Pessoas recém-chegadas à capital, sem tradição ou nome de família, mas com renda e propriedade. Alguns fizeram fortuna no Estado, outros já vieram com algum recurso de seus locais de origem. Seus negócios estavam, de alguma forma, ligados à produção da borracha, ou foram por ela incentivados em função da intensificação comercial e da demanda gerada pela maior circulação de pessoas e liquidez econômica.

Embora a fortuna lhes abrisse a possibilidade de participação no universo restrito da elite paraense, nem sempre ela era garantia de prestígio e reconhecimento. Fazia-se fundamental unir à riqueza outros fatores como nome e tradição familiar, o que poderia ser alcançado através de alianças comerciais e conjugais com membros das famílias locais. É sempre bom lembrar que para fazer parte dos grupos de elite, não é necessário apenas possuir bens e dinheiro. Deve-se aliar a estas prerrogativas a capacidade de mostrar-se e ser reconhecido como pertencente a uma determinada classe social, ter um status diferenciado. Elementos como comportamento, modos de falar, relacionamentos estabelecidos, roupas e educação constituem-se em alguns dos predicados que expressam a forma pela qual as pessoas se reconhecem na sociedade, determinam seu lugar, o qual deve não apenas ser mapeado por si, mas também pelos demais. Essa espécie de capital simbólico é tão fundamental quanto o conjunto de bens e riqueza mantidos pelos indivíduos. ${ }^{14} \mathrm{~A}$ origem e a trajetória familiar também se constituem em critérios fundamentais de pertencimento e de distinção dos grupos de elite. Os recursos da família são importantes para se definir a posição na hierarquia social; todavia, não menos importantes são as alianças de amizade e de afinidade constituídas pela parentela, formando uma rede de influência e de poder.

É nesse contexto que se deve entender as alianças matrimoniais em meio aos grupos de elite de Belém, formados por antigas linhagens de proprietários paraenses e indivíduos de fora do estado, e até mesmo do país, com recursos, mas sem tradição familiar.

Analisando as relações matrimoniais e a sociedade do século XIX no Pará, Marim, em seu trabalho pioneiro, destaca que:

As alianças matrimoniais se faziam em função da propriedade da terra. No século XIX, porém, com o desenvolvimento do comércio e com a maior integração com a economia mercantil, a forma monetária da riqueza começa a concorrer com a forma imobiliária. ${ }^{15}$

A autora continua evidenciando que a classe alta, criada nos anos anteriores da borracha dentro do aparelho do Estado, não contraiu muitas alianças com os segmentos dinâmicos da sociedade e seu poder foi sendo diluído.

É bem verdade que as famílias com fortunas pautadas preferencialmente na posse de terra e criação de gado tiveram seu poder diluído, como afirma a autora; afinal, novos grupos de comerciantes estrangeiros emergiram na capital. Entretanto, isso não implicou necessariamente na perda de sua rede de in- 
fluência e de patrimônio. Esse fato pode ser observado a partir do valor elevado dos legados deixados por representantes de algumas dessas famílias, ainda na virada do século XIX para o XX, e a contínua ocupação de cargos e funções públicas e administrativas por parte de seus membros.

Por outro lado, o revigoramento de algumas delas parece ter ocorrido justamente em função da agregação das atividades pecuaristas e de plantio à extração de seringa, como ocorreu com a família Pombo, cuja trajetória patrimonial foi observada no início deste trabalho; ou ainda, o estabelecimento de sociedade em firmas comerciais envolvidas, direta ou indiretamente, com o negócio da borracha.

Para que isso fosse possível, muitas famílias tiveram que flexibilizar suas atividades econômicas, muitas vezes fortalecidas a partir das alianças matrimoniais efetivadas. $\mathrm{O}$ casamento significou, para alguns desses indivíduos, a possibilidade de reestruturação do patrimônio, ou ainda, no caso daqueles com fortunas abaladas, a possibilidade dos descendentes conseguirem manter o padrão de riqueza e prestígio, através do dinheiro de comerciantes sem tradição e status social, mas com negócios rentáveis.

É importante neste ponto que se matize a trajetória deste grupo de comerciantes. É bem verdade que, com o crescimento da produção gomífera, houve o aumento no grupo de migrantes para a capital, com destaque para os estrangeiros que abriram novos negócios no Estado. Contudo, esse deslocamento não se deu apenas no momento de auge daquela economia, podendo ser encontrada a instalação de várias famílias de comerciantes em Belém, ainda na primeira metade do século XIX. Nomes como La Rocque, Castro e Costa destacavam-se na sociedade paraense do início dos oitocentos, com negócios direcionados preferencialmente para o comércio de mercadorias em geral, e da borracha, em particular. Mesmo alguns membros dessas famílias, pelo tempo em que se encontravam na província, investiram também na aquisição de propriedades rurais, ampliando seu leque de atividades, assim como na formação profissional de seus filhos, o que permitiu que, já na segunda metade do século XIX, eles fossem reconhecidos na sociedade local por atividades que extrapolavam o âmbito do comércio.

É nesse universo de uma elite proprietária de terra e gado, e ainda, comerciantes há mais tempo instalados na capital, que os recém-chegados homens de negócio vão estabelecer suas alianças, buscando associar à fortuna, o prestígio e o poder, critérios fundamentais para a ascensão na hierarquia social e a condição de pertencimento aos grupos de elite.

Uniōes que se tornam uma corrente contínua de obrigações e de reciprocidades e que ajudam a realizar e reforçar relações sociais. Para situar estas alianças destaco o exemplo do matrimônio de João Gualberto da Costa Cunha e Anna Cândida Malcher Cunha.

Maranhense, João Gualberto da Costa Cunha nasceu em 1844. Membro de uma importante e rica família de comerciantes daquela província, recebeu o nome homônimo de seu avô português que chegara ao Maranhão ainda no início do século XIX, onde recebera a insígnia de comendador. Uma vez em Belém, João Gualberto tornou-se um dos maiores comerciantes locais, participando de uma das firmas de aviamento mais importantes da cidade, a "Darlindo Rocha \& Companhia". ${ }^{16}$

Participou, ainda, da instituição e publicidade do Banco Emissor. Casou-se com Anna Cândida Malcher Cunha, filha de uma família de proprietários de terras concedidas por sesmarias. Seu pai, José da Gama Malcher, era médico, tendo ocupado diversos cargos na administração da província, como o de vereança, chegando mesmo a ser, durante muitos anos, intendente de Belém. ${ }^{17}$ Vê-se assim de que forma um migrante maranhense pertencente a uma rica família de origem portuguesa, casou-se com uma representante da elite local. Ao falecer em 1908, em Portugal, onde estava morando com Anna, João Gualberto, deixou um legado de trezentos e setenta e cinco contos de réis (23.609£) à viúva e seus 4 (quatro) filhos, afora o dinheiro da firma de aviamento que ficou para ser avaliado em uma sobrepartilha a acontecer posteriormente.

$\mathrm{Na}$ verdade, ao chegar ao Pará, João Gualberto não estava sozinho. Seu parente pela linhagem materna, Francisco Gaudêncio da Costa, irmão de sua mãe, era um rico comerciante instalado em Belém desde a primeira metade dos oitocentos. Francisco era casado com a paraense Carlota Pombo Brício, sobrinha do pecuarista Ambrozio Henrique da Silva Pombo, a quem já foi feita referência anteriormen- 
te. Carlota era também irmã de Maria Pombo Brício, casada com o Barão do Marajó, José Coelho da Gama e Abreu, que foi presidente da província do Pará em 1879.

Esses dados deixam claro como membros de duas gerações de uma mesma linhagem de comerciantes vindos de fora da província, o português Francisco, e o maranhense João Gualberto, casaram-se com mulheres de famílias tradicionais paraenses, proprietárias de terra, firmas comerciais e com grande influência na política local; afinal, a cunhada de Francisco fora casada com um presidente de província, e seu sobrinho, João Gualberto, casou-se com a filha de um intendente da capital paraense.

Através dessas alianças, as famílias fortificavam o patrimônio e ampliavam a rede de influência política, o que, particularmente para os migrantes, poderia tornar-se um elemento importante de integração à sociedade e aos espaços de sociabilidade da elite local.

A propósito da realização de casamentos com famílias tradicionais locais, alguns dos homens de negócio recém-chegados também efetivaram alianças com membros de famílias comerciantes que se estabeleceram na província paraense ainda no início do século XIX, portanto, antes mesmo do grande desenvolvimento da economia gomífera.

É o que se depreende do casamento de duas gerações ocorrido entre as famílias La Rocque e Costa. De origem francesa, os La Rocque chegaram a Belém através de Portugal, ainda na primeira metade do século XIX. Envolvidos com o comércio, tornaram-se também proprietários de engenhos em localidades próximas à Belém. Um de seus membros, Luiz de La Rocque, possuía uma firma comercial, "La Roque \& Varella", além de ser proprietário de engenho de açúcar e serraria. Luiz casou-se com Emilia da Costa, filha do comerciante português, já referido, Francisco Gaudêncio da Costa. Estabelece-se dessa maneira o enlace de duas famílias de comerciantes estrangeiros através do matrimônio de uma primeira geração.

Por sua vez, a filha de Luiz de La Rocque, de nome Emília, como o da mãe, casou-se com Bento Rabello, comerciante português, proprietário de uma das maiores casas de aviamento existentes à época, a "Darlindo Rocha \& Cia”. Firma esta da qual era sócio João Gualberto da Costa, parente de Emília pela linha paterna. Há nessas alianças uma forte imbricação entre casamento, parentesco e sociedade comercial, evidenciando o jogo de troca e estabelecimento de alianças que envolviam os casamentos nos grupos de proprietários.

A partir das alianças, auxílios financeiros e novos negócios podiam ser estabelecidos entre parentes. Foi assim que Luiz de La Rocque comprou um terreno de seu genro, Bento Rabello, no mesmo ano em que este se casou com sua filha, ficando-lhe devendo o pagamento do mesmo, após seu falecimento. Da mesma forma, Luiz de La Rocque devia dinheiro corrente a outro genro, de nome Antonio Aureliano Eirado, casado com sua filha, Rosa. ${ }^{18}$

As alianças conjugais envolvendo comerciantes da família Cunha com membros de outros grupos ligados ao comércio não terminam aí. Os irmãos de João Gualberto da Costa Cunha, os brasileiros Antonio José da Costa Cunha e Alberto Eduardo da Costa, casaram-se com as filhas do proprietário de uma sólida casa de aviação, a "Ribeiro da Silva \& Cia", chamado José Caetano Ribeiro da Silva. ${ }^{19}$ Vê-se, assim, a configuração de uniōes unilaterais envolvendo dois irmãos brasileiros, com ascendência portuguesa, e duas irmãs paraenses, filhas de um rico comerciante português já estabelecido na capital.

É necessário destacar ainda que todos os comerciantes da família Cunha aqui citados, em particular Francisco, João Gualberto e Antonio, assim como os homens de negócios com quem estes estavam envolvidos pelas diversas alianças matrimoniais estabelecidas, em particular, Bento Rabello e José Caetano Ribeiro da Silva, eram membros da Praça do Comércio e participaram das reunióes que reorganizaram aquela associação, tendo seus nomes revezados nos seus diversos cargos, desde a presidência às diretorias. ${ }^{20}$

Esse fato realça como esses indivíduos pertencentes à elite mercantil estavam imbricados em relaçóes de parentesco e afinidade, bem como nos negócios e na organização política, atualizada no fortalecimento do que viria a ser a Associação Comercial Paraense. Essa imbricação faz pensar que os enlaces matrimoniais poderiam potencializar, ou serem potencializados, por possíveis apoios na participação de cargos e funçóes dentro daquela instituição, que congregava os principais homens de negócio do Estado. O casamento se forja, dessa maneira, enquanto mediador de relaçôes de parentesco, comerciais e apoios políticos. 
Pois bem, as trajetórias das últimas alianças aqui pontuadas deram conta dos matrimônios envolvendo famílias tradicionais com comerciantes estrangeiros ou filhos de estrangeiros naturalizados. $\mathrm{Ou}$ mesmo, a união destes indivíduos com famílias de outros comerciantes, muitos deles há mais tempo instalados no Pará, em períodos que antecedem a expansão da economia gomífera. Entretanto, o fato de encontrar casamentos envolvendo pessoas com estes perfis distintos de naturalidade e negócio, embora aponte para uma tendência de ampliação da ocorrência de alianças exogâmicas e horizontais nos grupos da elite local, não significa dizer que alianças verticais e endogâmicas não continuassem a se estabelecer, principalmente em meio às tradicionais famílias proprietárias de terra e gado.

Algumas delas continuaram procurando definir alianças matrimoniais internas ao grupo de parentesco ao longo do século XIX, particularmente no período que antecede o auge da economia da borracha. Estas uniões serviam de estratégia de conservação do patrimônio, ao mesmo tempo em que restringiam a entrada de indivíduos sem linhagem na rede familiar.

Para exemplificar esta questão, destaco o casamento entre primos que envolveram, pelo menos, dois ramos de importantes famílias paraenses.

Catharina Ignacia do Espírito Santo, casada com Marcellino José Correa de Miranda, eram proprietários de engenho em Igarapé-Miry, uma vila próxima à cidade de Belém. No engenho, onde utilizavam mão-de-obra escrava, possuíam alambique para fabrico de aguardente. Catharina faleceu em 1825, deixando oito filhos, entre eles Antonio Francisco Corrêa de Miranda e Justo Jose Corrêa de Miranda. ${ }^{21}$

Antonio mudou de nome e virou Antonio Francisco Corrêa Caripuna, ${ }^{22}$ casou-se, recebeu a patente de coronel da guarda nacional, tornou-se proprietário de engenhos e fazendas na região de Abaeté, onde mantinha um dos maiores plantéis de escravos encontrados ao longo da pesquisa. ${ }^{23}$ Seu irmão, Justo José Correa de Miranda, nasceu em Igarapé-Miry, onde mantinha seus engenhos e, tal qual o irmão, a patente de coronel e um plantel significativo de escravos. ${ }^{24}$ Ambos mantiveram os negócios da família voltados para o cultivo e ampliaram os bens comprando casas em Belém. A proximidade entre os irmãos não termina aí. Os dois casaram-se, em primeiras núpcias, com mulheres da família Castilho, Isabel e Maria do Carmo, provavelmente irmãs.

Se o casamento dos pais ocorreu entre mulheres da mesma família, o mesmo tipo de arranjo matrimonial pôde ser encontrado na geração seguinte formada por seus filhos. Adelaide e Anna, filhas de Antonio, casaram-se com seus primos, Firmino e Antonio, filhos de Justo, estabelecendo-se assim uma troca unilateral, onde dois irmãos casam-se com duas irmãs.

Neste caso, tem-se portanto o casamento unilateral exogâmico, na geração ascendente dos irmãos, Corrêa de Miranda, e as irmãs, Castilho; e, na geração seguinte, o casamento unilateral endogâmico, desta feita envolvendo primos. Estes arranjos demonstram a recorrência de uniōes verticais presentes nessa família de tradicionais proprietários de engenho e escravos do interior do Estado, que possuíam imóveis e casas de morada em Belém.

Essa estratégia matrimonial vai ser muito utilizada também em outras famílias de fazendeiros e criadores de gado tradicionais da capital. Veja-se o exemplo da família Pombo. Um de seus membros, Ambrósio Henrique da Silva Pombo, que, como já visto, era criador de gado na Ilha do Marajó, tendo só posteriormente se envolvido com a extração de seringa, casou-se com Floripes, que era oriunda de duas grandes famílias de fazendeiros e criadores de gado, também do Marajó, Chermont e Miranda. Floripes possuía uma irmã de nome Ignês Chermont de Miranda, que se casou com Francisco Acácio Corrêa, advogado, conhecido como o Barão de Guamá. ${ }^{25}$

Estava assim constituída a rede de matrimônios exogâmicos de uma mesma linha de gerações: Ambrósio e Floripes, de um lado, Ignês e Francisco Acácio, de outro. É na geração seguinte que vai ocorrer o casamento endogâmico entre os primos: Maria e José, filhos de Ambrósio e Floripes, casaram-se com seus primos paralelos maternos, Edgar e Clotilde, filhos de Ignês com o Barão de Guamá.

Este é apenas um exemplo de casamento entre primos ocorrido em meio às famílias Pombo, Chermont e Miranda. Eles ocorreram em diversas gerações dessas famílias. Para se ter uma ideia, os pais de 
Ambrósio Henriques da Silva Pombo eram igualmente primos. Seu pai, João Florêncio, casou-se com a prima, Maria Emilia Pombo Garcez Moncada.

Em alguns casos, essas alianças eram arranjadas e tinham que acomodar as expectativas dos indivíduos às necessidades do grupo de parentesco. No entanto, nem sempre esse equilíbrio era encontrado e, quando isso ocorria, os arranjos matrimoniais não seguiam de acordo com as expectativas parentais.

Foi assim com o casamento de Maria de Nazareth Ferreira Gomes de Miranda, filha do Capitão Antonio Gomes Corrêa de Miranda, proprietário de terra e criador de gado na vila de Cachoeira, ilha do Marajó. Apenas metade dessas terras pertencia ao capitão Antonio, correspondendo a outra metade restante aos seus irmãos, José dos Passos e Marcello Gomes Corrêa de Miranda. ${ }^{26}$ Eles eram também sócios de uma firma de criação de gado existente naquelas fazendas e administradas por Antônio, desde o ano de $1858 .{ }^{27}$

A reagregação da fazenda e a consolidação da sociedade foi resolvida através do casamento de Maria de Nazareth com o irmão de seu pai, o já referido, José dos Passos. Com este arranjo matrimonial entre tio e sobrinha, as terras não apenas não permaneceriam divididas, como se manteriam exclusivamente no grupo de parentesco. O pai de Maria, Antonio, faleceu em 1871, ficando a fazenda sendo administrada pela firma Miranda \& Irmãos. Quando, treze anos mais tarde, José dos Passos vem também a falecer, fica-se sabendo que ele encontrava-se separado de Maria há cerca de dez anos. Isso significava que, pouco tempo depois da morte do capitão Antônio, sua filha e seu irmão separaram-se. ${ }^{28}$

Do casamento, Maria e José dos Passos tiveram uma filha que não vivia com a mãe, e sim, com uma tia pela linha paterna. Enquanto era vivo, José dos Passos residia em Belém, onde teve outra filha, já depois da separação, com uma mulher solteira. Maria foi viver em um vilarejo no rio Guajará, voltando a casar-se, desta feita com Antonio Luiz de Azevedo, com quem, por sua vez, também teve outro filho. Ele era um pequeno proprietário de terras com plantação de cacau e algumas árvores de seringueira, sem grandes posses ou pertencimento a um clã familiar tradicional. ${ }^{29}$

Com o fim do casamento de primeiras núpcias com o irmão de seu pai, Maria ficou sem nenhum bem da família. Somente após o falecimento de José dos Passos ela herdou três pequenas casas localizadas em Belém, não tendo obtido qualquer parte nas fazendas e no gado existente na ilha do Marajó.

O segundo marido de Maria, Antonio, morreu quatro anos depois de José dos Passos, em 1888. Seu legado não ultrapassou os dez contos de réis (401£), sendo que, dentre os bens arrolados de maior valor, encontravam-se as casas, localizadas em Belém, que fizeram parte da herança deixada por José dos Passos a Maria. Ao separar-se do irmão de seu pai, rompendo a aliança matrimonial estabelecida no universo da rede de parentesco, e ainda, casando-se com um indivíduo sem posses, Maria não teve direito à maior parte dos bens familiares, não apenas logo após a separação, como também depois da morte do marido. Somese a isso o fato dela não ter criado a filha, não se sabe se por opção ou imposição familiar, mas a questão é que a menina ficou com a parentela, permanecendo desta forma integrada à rede familiar, embora a mãe pareça ter sido alijada da mesma, tendo em vista o fato de não ter recebido grande parte de sua herança.

Esta história mostra que o casamento entre as famílias de proprietários de terra e gado paraense envolvia acordos pessoais, familiares e patrimoniais, entretanto, eles não necessariamente eram estabelecidos sem tensões e conflitos. As famílias nem sempre conseguiam dar conta das contingências patrimoniais e das inclinações individuais de seus membros, quando da organização das alianças matrimoniais. A trajetória de Maria me permite dar visibilidade às dificuldades e fissuras internas dos proprietários de terra e gado, quebrando imagens homogêneas e uníssonas que possam ter sido criadas sobre este segmento.

Do que foi exposto, posso afirmar que os casamentos verticais envolvendo pessoas de famílias tradicionais da elite paraense ainda se faziam presentes, particularmente nos anos que antecedem o auge da economia gomífera. A partir daí, as alianças horizontais com comerciantes e migrantes estrangeiros/nacionais ganham cada vez mais espaço. Na verdade, se os arranjos matrimoniais exogâmicos sempre existiram na província, desde o período colonial, ${ }^{30}$ eles ganharam uma nova particularidade nos oitocentos, em função da intensificação do número de migrantes que tiveram oportunidade de fazer fortuna considerável a partir da economia da borracha, criando uma elite mercantil ampla e fortalecida. Este grupo, 
voltado nitidamente para o comércio, passou a ocupar cada vez mais espaços organizacionais, reforçar associações, como a do comércio, investir em serviços urbanos, com destaque para a Companhia das Águas do Pará ${ }^{31}$ estendendo sua rede de poder e de influência frente aos grupos preponderantemente agrários, que tiveram que se readaptar em função das mudanças a partir daí engendradas.

Menos do que construir genealogias, o que procurei fazer ao descrever a trajetória dos enlaces aqui traçados é evidenciar a complexidade das alianças, as diversas articulações que elas acionavam, bem como o jogo de estratégias que elas podiam envolver. As uniões exogâmicas tornaram-se cada vez mais presentes no final dos oitocentos, o que não significa que as uniōes endogâmicas não continuassem ocorrendo, entretanto elas vão, cada vez mais, ter que dividir espaço com os casamentos envolvendo pessoas de fora das linhagens tradicionais do Estado. E isto se deu, em grande parte, pela necessidade das famílias locais investirem em atividades associadas direta ou indiretamente, à borracha e ao comércio, evidenciando o diálogo entre as mudanças econômicas e as relações familiares. Da mesma forma, havia a necessidade dos ricos homens de negócio - estrangeiros e nacionais -, fortalecerem sua rede de influência e organização política, ampliando seu prestígio e status na sociedade local.

Do que foi dito, compreende-se que as alianças entre as famílias dos diversos segmentos sociais da elite conformavam não apenas laços matrimoniais, mas também relações comerciais envolvendo redes de parentesco e afinidade que impulsionavam atividades, negócios, associações e auxílios financeiros em diversos níveis.

\section{Contratos nupciais}

Passo agora a analisar alguns contratos de dotação nupcial que encontrei nos inventários pesquisados, e que vão ser discutidos no sentido de compreender melhor o perfil das alianças matrimoniais dos grupos de elite. De alguma forma, esses contratos dão visibilidade às assimetrias de renda e status existentes no interior desse segmento, o que me permite retomar as diferenças e singularidades presentes entre os proprietários.

Contudo, antes é necessário se entender um pouco mais acerca da legislação que envolvia estes contratos, começando por enfatizar que o sistema de casamento português, atualizado no Brasil, estabelecia a comunhão total de bens, que poderia não ser adotada pelo casal, sendo, nesses casos, necessário assinar uma escritura de contrato antenupcial. Esses sistemas matrimoniais estavam contemplados nas Ordenaçôes Filipinas, que permitiam aos cônjuges o seu estabelecimento. Segundo Samara:

O regime de comunhão de bens, com os cônjuges meeiros,era usualmente adotado na metrópole e conseqüentemente no Brasil, enquanto dependente de Portugal, sistema que se perpetuou durante o Império." [E ainda], "os consórcios não especificamente englobados nessa prática comum, estabeleciam as regras através dos contratos ante-nupciais. ${ }^{32}$

A mesma disposição foi reiterada no Código Civil Brasileiro de 1916, que estabelecia quatro espécies de regime de bens no casamento: "a) comunhão universal; b) comunhão parcial; c) separação; d) dotal. Podem os contrahentes escolher um desses regimes, ou modificá-los, e combiná-los entre si, de modo a formar uma nova espécie." ${ }^{33}$

Em meio aos inventários, encontrou-se 15 (quinze) casais que estabeleceram escrituras de contrato antenupciais, sendo as mais comuns aquelas que determinavam a separação total de bens seguida de disposição dotal. Isso significa dizer que os bens do casal ficavam incomunicáveis, ou seja, tudo aquilo que por herança, doação, legado, enfim, qualquer aquisição gratuita ou onerosa que os cônjuges viessem a receber, não poderia ser partilhada pelo(a) viúvo(a). E, ainda, pela disposição dotal, os bens da noiva já existentes ou adquiridos durante a vigência do matrimônio, gozariam de todos os privilégios de um dote, entre eles, o fato de voltar aos seus ascendentes ou tutores, no caso de falecimento ou separação. Como, na maioria das vezes, eram os pais ou tutores que doavam à mulher os bens com os quais ela entrava no casamento, ficava assim assegurada a possibilidade de retorno do benefício se algo ocorresse, como uma separação ou ausência de herdeiros. 
Esse acordo incluía, da mesma forma, o privilégio dos bens serem inalienáveis, o que significa dizer que "não ficarão sujeitos a pagamentos de dívidas contrahidas antes ou depois do matrimonio ainda que ella para isso tenha emprestado sua outorga e assignatura porque dado tal caso desde já reclama como constrangida e por obediência a seu marido." ${ }^{34} \mathrm{O}$ esposo poderia ter o usufruto e a administração dos bens que a noiva trazia para o casamento, porém não poderia deles tomar posse. Nem, tampouco, deles fazer uso para pagamento de dívidas e empréstimos contraídos, evitando assim que o patrimônio da família ascendente da noiva fosse prejudicado pelos reveses dos negócios do marido.

Nesses contratos de separação de bens e dote, o noivo também podia dotar a noiva, e isso ocorria com certa frequência nos acordos. Nestes casos, o valor ou bem dotado gozava dos mesmos privilégio dos bens que ela, esposada, trazia para o casamento.

De forma sintética, as disposições acima apontadas transformavam em regime dotal todo e qualquer bem que a mulher conduzia para o casamento e aqueles que ela recebia do marido sob forma de dote. Essas determinaçōes fazem pensar que "os contratos matrimoniais pré-nupciais visavam claramente a proteger os bens de cada um dos cônjuges dos direitos do outro cônjuge dentro do sistema de comunhão de bens. Assim é possível que os contratos reflitam a desigualdade econômica inicial entre os cônjuges". ${ }^{35} \mathrm{Ou}$ seja, no caso de casamentos assimétricos, o cônjuge com maior fortuna usava o regime de separação de bens como forma de preservação e garantia do patrimônio individual e familiar. Quando esta situação cabia à mulher, seus bens não poderiam ser possuídos pelo marido, apenas administrados. No caso de ser o esposo o cônjuge de maior fortuna, ele legava à mulher apenas o dote concedido ao casar, ficando esta sem direito a outros bens do casal no momento da partilha, salvo disposição testamentária em contrário.

Dos 15 (quinze) contratos levantados, um pouco mais da metade deles envolvia indivíduos estrangeiros, mais especificamente portugueses, havendo apenas um dentre eles que era de nacionalidade francesa. Em meio aos estrangeiros, todos eram comerciantes com fortunas que poderiam variar em torno de cem a trezentos contos de réis, havendo um único caso de um comerciante cujo monte-mor alcançou a faixa dos oitocentos contos de réis. Pelo valor médio dos legados posso aferir que as pessoas que procuravam esse tipo de acordo, embora tivessem recursos, nem sempre possuíam somas volumosas ou eram necessariamente grandes proprietários.

Dentre os casais que adotaram a separação dos bens e dotação, encontrou-se apenas um caso de proprietário de terra e criador de gado. Nesta condição encontravam-se José Teixeira e Irene Góes, que se constituíam também, em um dos três únicos casais paraenses a estabelecer o contrato antenupcial de casamento. Pois, como se disse, esses acordos eram mais comumente presentes nos matrimônios envolvendo estrangeiros.

É interessante observar que a maior parte dos documentos cotejados foram contratados no século XIX, sendo verificado apenas 1 (um) para o século XX, datado de 1912. Por sua vez, os dotes estabelecidos pelos maridos variavam em valor, mas todos eles ficaram em torno de 10:000\$000 (dez contos de réis) a 30:000\$000 (trinta contos de réis), quantias pouco volumosas.

Os poucos contratos de dotação encontrados para o século XX e o pequeno valor atribuído ao dote corroboram os argumentos de Nazzari sobre a decadência dessa prática na sociedade brasileira, onde cada vez diminuía mais o número de famílias e maridos que dotavam suas filhas e esposas, respectivamente; assim como se verifica a queda no valor do dote concedido, o que se justifica pelo crescimento do individualismo e a separação entre família e negócio. ${ }^{36}$

E isto era fato também nos dotes atribuídos pelos maridos às esposas. Basta citar que o comerciante português Bento Rabello de Andrade dotou sua esposa, Emilia La Roque, em vinte contos de réis, em 1875 , um valor que não chega a alcançar nem $3 \%$ do seu patrimônio avaliado em cerca de oitocentos e dezoito contos de réis quando de seu falecimento. ${ }^{37}$

Em geral, o dote era feito em moeda, não se encontrando casos em que o marido dotava a esposa através de bens imobiliários ou títulos. Quando a esposa se dotava, ou por outra, atribuía aos bens que trazia para o casamento os privilégios do regime dotal, esses bens, frequentemente, encerravam casas, terrenos e, menos regularmente, ações e títulos. 
Em alguns casos, o contrato previa a quebra da incomunicabilidade dos bens, se o casal viesse a ter filhos. É o caso da escritura assinada em 1886 pelo português Julio Lambert Pereira, 31 anos de idade, e a paraense Olívia Pereira da Motta, de 21 anos de idade. Nela os cônjuges asseguram que, "se houver filhos ou filhas de seu matrimônio, por morte de um dos conjuges, haverá perfeita comunhão de bens, pertencendo metade do monte ao conjuge sobrevivente e a outra metade ao filho ou filhos existentes." ${ }^{38} \mathrm{E}$ de fato ao falecer no ano de 1913, Olívia ficou com a metade do legado do marido, enquanto seus cinco filhos herdaram a outra metade.

Diferentemente do contrato acima, no acordo assinado pelo comerciante pernambucano Tiburcio Victor da Silva Santos e Maria Franco, não havia a cláusula relativa à presença de filhos como consequente motivo de suspensão do acordo. Na escritura, os bens do casal ficam incomunicáveis e o noivo dotava Maria dez contos de réis. Desse modo, quando Tiburcio faleceu, em 1910, Maria recebeu apenas o valor de seu dote, sendo os bens do marido delegados exclusivamente aos sete filhos que o casal tivera. ${ }^{39}$

Um terceiro tipo de contrato podia ser encontrado onde apenas os bens de um dos cônjuges tornavam-se incomunicáveis. Exemplo desse modelo foi a escritura de pacto antenupcial de Maria Augusta Pinto, de 24 anos, paraense, embora nascida na Áustria-Hungria, e Heráclito Marcellino de Brito Pereira, de 24 anos, paraense, engenheiro eletricista. Maria era sobrinha do Dr. Paes de Carvalho, ${ }^{40}$ seu tio materno, na casa de quem vivia na cidade de Paris, onde também morava seu noivo. O casamento realizado em Paris, em 1912, na casa da contraente, ocorreu sob regime de separação e dote. Assim, todos os bens que ela trazia para o casamento ficavam incomunicáveis; no entanto, os bens pertencentes ao marido vigorariam sob o regime de comunhão.

Antes de falecer, no ano de 1918, Maria fez um testamento instituindo Heraclitto seu universal herdeiro, retirando assim as restrições de posse de seus bens dotais por parte do marido, que, dessa forma, receberia metade do valor dos mesmos, ficando a outra metade aos quatro filhos que o casal tivera. ${ }^{41}$

$\mathrm{Na}$ maior parte dos contratos, os noivos reservavam-se o direito de disposição testamentária de seus bens, podendo nesse momento revogar as determinações do contrato antenupcial.

Pelo exposto, conclui-se que a maior parte das escrituras de contrato antenupcial pautavam-se na separação total dos bens e de dote, sendo que alguns acordos acenavam com a possibilidade de haver a comunhão dos bens, no caso da existência de filhos. Embora houvesse paraenses, o número de estrangeiros, em particular, portugueses, casados com mulheres brasileiras, ou mesmo com suas conterrâneas, foi mais significativo dentre os casais que assinaram esses contratos.

Como, em boa parte, eles eram proprietários que tinham no comércio sua principal fonte de renda, fica sugerido que naqueles casos em que a família da esposa dotava-a, ficando seus bens incomunicáveis com os do marido, havia a possibilidade disso constituir uma estratégia de manutenção de seu patrimônio, que, dessa maneira, ficava a salvo dos reveses da economia e dos negócios do esposo. Por outro lado, nos casamentos em que não prevalecia a simetria de riqueza e prestígio, esses acordos podiam significar uma tentativa de assegurar a manutenção do patrimônio por parte do cônjuge de maior fortuna, resguardando seus bens de possíveis separações ou unióes sem prole. Em alguns casos, no entanto, essas disposições contratuais foram revogadas por testamento e a comunhão dos bens passou a vigorar, o que ocorreu com maior frequencia naquelas uniões que resultaram na existência de filhos.

Neste trabalho, ao tomar as famílias e o casamento em meio à elite local como objeto de análise, procurei dar conta das distinções existentes no interior destes grupos. Distinçôes que se atualizaram nas diferenças de naturalidade, tempo de residência na capital paraense, renda, prestígio e tipo de atividade/ negócio. Especificidades que se compreendem melhor quando caracterizado o perfil dos bens desses indivíduos e famílias, observando como ele foi se transformando em função das mudanças impulsionadas pela economia da borracha. Estas alterações puderam ser sentidas nas estratégias de alianças endogâmicas e exogâmicas que envolveram os casamentos entre famílias com trajetórias e configurações particulares, bem como assimetrias de renda e prestígio, que os contratos de dotação expuseram mais claramente. Desta forma, espero ter mostrado de que maneira o estudo das relaçôes familiares e do ca- 
samento podem ajudar a trazer um novo olhar sobre a economia, diversificando e trazendo mais complexidade à análise. Assim como a configuração econômica pode se tornar fundamental à compreensão dos arranjos matrimoniais efetivados. A História da família torna-se deste modo um recorte importante para a análise da época pesquisada, atraindo novas perspectivas de olhar à Belém da borracha.

\section{Notas}

${ }^{1}$ MEIRA FILHO, Augusto. A capela do senhor dos passos. In: Revista do Instituto Histórico e Geográfico do Pará, vol. XVI e XVII, 1969/1970, pp. 141-155.

${ }^{2}$ BEZERRA NETO, José Maia. Escravidão negra no Grão-Pará. Belém: Pakatatu, 2001, p. 79.

${ }^{3}$ ATJEPA/ Cartório Odon Rhosard, caixa 1865-1866, ano: 1866.

${ }^{4}$ ATJEPA/ Cartório Odon Rhosard, maço 04, ano: 1893.

${ }^{5}$ PARÁ - Secretaria do Governo, Manoel Baena. Relatório apresentado ao governador do estado em fevereiro de 1895. Pará: Typ. do Diário Official, 1895, pp. 95-97.

${ }^{6}$ WEINSTEIN, Barbara. A borracha na Amazônia: expansão e decadência (1850-1920). São Paulo: Hucitec/Edusp, [1983] 1993 , p. 58.

${ }^{7}$ HEINZ, Flávio (org). Por outra história das elites. Rio de Janeiro: FGV, 2006.

${ }^{8}$ ATJEPA/ Cartório Odon Rhosard, caixa 1872, ano: 1872.

${ }^{9}$ ATJEPA/Cartório Odon Rhosard, caixa 1880, ano: 1880.

${ }^{10}$ Casas aviadoras eram os estabelecimentos comerciais que abasteciam os seringais de mercadorias gerais como alimentos, roupas e utensílios, recebendo, em troca, o pagamento em borracha. O preço alto cobrado pela consignação de mercadorias aos seringueiros e o baixo preço pago na hora de comprar a produção da borracha eram reclamações constantes desses trabalhadores, que dificilmente conseguiam saldar suas dívidas com a casa aviadora.

${ }^{11}$ WEINSTEIN, Barbara. Op. cit., p. 107.

${ }^{12}$ BORGES, Ricardo. Vultos notáveis do Pará. Belém: CEJUP, 1986, pp. $92-93$.

${ }^{13}$ ATJEPA/Cartório Odon Rhosard, maço 01, ano: 1882.

${ }^{14}$ BOURDIEU, Pierre. Condição de classe e posição de classe. In: AGUIAR, Neuma. Hierarquias em classes. Rio de Janeiro: Zahar, 1973, p. 65.

${ }^{15}$ MARIN, Rosa Acevedo. As alianças matrimoniais na alta sociedade paraense no século XIX. In: Revista Estudos Econômicos, no ${ }^{\circ}$. São Paulo: Instituto de Pesquisas Econômicas da Faculdade de Economia e Administração da Universidade de São Paulo (IPE-USP), 1985.

${ }^{16}$ ATJEPA/ Cartório Odon Rhosard, maço 27, ano: 1908.

${ }^{17}$ BORGES, Ricardo. Op. cit., pp. 92-93.

${ }^{18}$ ATJEPA/ Cartório Odon Rhosard, maço 04, ano: 1893.

${ }^{19}$ ATJEPA/Cartório Odon Rhossard, maço 16 e 28, ano: 1900 e 1909.

${ }^{20}$ CRUZ, Ernesto. História da Associação Comercial do Pará. 2o ed. Belém: Ed Universitária do Pará, 1996, pp. 157, $167-$ $185,189$.

${ }^{21}$ ATJEPA/ Cartório Odon Rhosard, caixa 1824-1825 ano: 1825.

${ }^{22} \mathrm{O}$ uso de nomes e topônimos de cunho indígena e nativista vai ser comum no período anterior e posterior à independência brasileira. Essa mesma prática vai ser encontrada em meio a membros de outros ramos familiares brasileiros como os $\mathrm{Su}-$ assuna TERRUYA TERUYA, Marisa. Trajetória sertaneja: um século de poder e dispersão familiar na Paraíba. Tese de doutorado apresentada ao Programa de Pós-Graduação em História Social da USP, São Paulo, 2002, p. 129.

${ }^{23}$ ATJEPA/ Cartório Odon Rhosard, caixa 1865-1877 ano: 1877.

${ }^{24}$ ATJEPA/ Cartório Odon Rhosard, caixa 1878, ano: 1878.

${ }^{25}$ ATJEPA/ Cartório Odon Rhosard, maços 03,16,61, anos: 1892, 1901, 1929.

${ }^{26}$ ATJEPA/ Cartório Odon Rhosard, caixa 1871, ano 1871.

${ }^{27}$ Diário do Comercio, 07.02.1859, p. 04.

${ }^{28}$ ATJEPA/ Cartório Odon Rhosard, caixa 1884, ano 1884.

${ }^{29}$ ATJEPA/ Cartório Odon Rhosard, caixa 1888, ano 1888. 
${ }^{30}$ Embora as uniōes endogâmicas tenham se destacado nos casamentos de famílias da elite realizados durante o período colonial, as alianças envolvendo não parentes também se faziam presente, sendo mais ou menos utilizadas, de acordo com algumas variáveis tais como: o isolamento geográfico do grupo, as estratégias de manutenção do patrimônio, a presença da migração e a estrutura política, administrativa e militar da localidade, abrindo espaço para a maior ou menor presença de reinóis com importantes cargos. Em Belém, Batista mostra a recorrência com que as uniōes endogâmicas vão se dar, em paralelo com a exogamia encontrada nas uniōes das famílias Pombo, Henriques, Ayres, Bricio, Miranda, Chermont e Lacerda BATISTA, Luciana Marinho. Muito além dos seringais: elites, fortunas e hierarquias no Grão-Pará, c.1850 - c. 1870 . Dissertação de Mestrado apresentada ao Programa de Pós-Graduação em História Social da UFRJ, Rio de Janeiro, 2004.

${ }^{31}$ A Companhia das Águas de Belém foi um importante empreendimento na área dos serviços públicos, tendo funcionado entre os anos de 1881 a 1895 . Dentre seus diretores estavam nomes como os dos comerciantes João Luiz e Antonio de La Rocque e, ainda, em meio aos acionistas, contavam grande parte dos comerciantes proprietários de casas aviadoras em Belém, como Bento Rabello de Andrade. PARÁ - Secretaria do Governo, Manoel Baena. Relatório apresentado ao governador do estado em fevereiro de 1895. Pará: Typ. do Diário Official, 1895, p. 10.

32 SAMARA, Eni de Mesquita. O dote na sociedade paulista do século XIX: legislação e evidências. In: Anais do Museu Paulista. Tomo XXX. São Paulo: USP, 1980/1981, pp. 41- 53.

${ }^{33}$ MIRANDA, João Evangelista. Guia do tabellião - de acordo com o novo código civil brasileiro e mais legislação em vigor. Pará/Belém: Typ. da Livraria Gillet, 1927, p. 115.

${ }^{34}$ Escriptura antenupcial de Leonardo José da Silva e Maria José de Azevedo Portal. ATJEPA/Cartório Odon Rhosard, maço 14, ano: 1899 .

${ }^{35}$ NAZZARI, Muriel. O desaparecimento do dote: mulher, famílias e mudança social em São Paulo, 1600-1900. São Paulo: Companhia das Letras, 2001 [1991], p. 232.

${ }^{36}$ NAZZARI, Muriel. Op. cit., p. 189.

${ }^{37}$ ATJEPA/Cartório Odon Rhosard, maço 15, ano: 1900.

${ }^{38}$ Escritura de contrato Antenupcial. Inventário Julio Lambert Pereira. ATJEPA/Cartório Odon Rhosard, maço 34, ano 1913.

${ }^{39}$ ATJEPA/Cartório Odon Rhosard, maço 28, ano 1910.

${ }^{40}$ José Paes de Carvalho foi um dos fundadores do Clube Republicano no Pará. Era médico, tendo sido Governador do Estado entre os anos de 1897 a 1901 e Senador federal em 1903. Após esse período, mudou-se para Paris, onde viveu por mais de 40 anos e veio a falecer, em 1943. BORGES, Ricardo. Op. cit., pp. 176-181.

${ }^{41}$ ATJEPA/Cartório Odon Rhosard, maço 43, ano 1919.

\section{Referências bibliográficas}

BATISTA, Luciana Marinho. Muito além dos seringais: elites, fortunas e hierarquias no Gräo-Pará, c.1850 - c. 1870. Dissertação apresentada ao programa de Pós-Graduação da UFRJ. Rio de Janeiro, 2004.

BEZERRA NETO, José Maia. Escravidão negra no Grão-Pará. Belém: Pakatatu, 2001.

BORGES, Ricardo. Vultos notáveis do Pará. Belém: CEJUP, 1986.

BOTELHO, João José da Costa. A família Castro no Pará. Belém: Falangola, 1983.

BOURDIEU, Pierre. Condição de classe e posição de classe. In: AGUIAR, Neuma. Hierarquias em classes. Rio de Janeiro: Zahar, 1973.

CANCELA, Cristina Donza. Casamento e relaçôes familiares na economia da borracha. Belém (1870-1920). Tese de doutorado apresentada ao Programa de Pós-Graduação da USP. São Paulo, 2006.

CRUZ, Ernesto. História da Associação Comercial do Pará. 2º ed. Belém: Ed Universitária do Pará, 1996.

CUNHA, Raymundo Cyriaco. Paraenses illustres. 2o ed. aumentada. Belém: Typ. de J.B. dos Santos, 1900.

HEINZ, Flávio (Org). Por outra história das elites. Rio de Janeiro: FGV, 2006.

KUZNESOF, Elizabeth. A família na sociedade brasileira: parentesco, clientelismo e estrutura social, São Paulo, 1700-1980. In: Revista Brasileira de História - Famílias e Grupos de Convívio. São Paulo: ANPUH/Marco Zero, ago. 88/ fev. 89, pp. 37-64.

LEWIN, Linda. Some historical implications of kinship organization for family-based politics in the brazilian northeast. V. 27, no 2. In: Comparative Stuties in Society and History, 1979.

MARIN, Rosa Acevedo. As alianças matrimoniais na alta sociedade paraense no século XIX. In: Revista Estudos 
Econômicos. no 15, São Paulo: Instituto de Pesquisas Econômicas da Faculdade de Economia e Administração da Universidade de São Paulo (IPE-USP), 1985.

MEIRA FILHO, Augusto. A capela do senhor dos passos. In: Revista do Instituto Histórico e Geográfico do Pará, vol. XVI e XVII. Pará: Officinas Gráficas do Instituto Lauro Sodré, 1969/1970.

MELLO, Zélia Cardoso de. Metamorfoses da riqueza - São Paulo, 1845-1895. São Paulo: Hucitec,/ Secretaria Municipal de Cultura, 1985.

MIRANDA, João Evangelista. Guia do tabellião - de acordo com o novo código civil brasileiro e mais legislação em vigor. Pará/Belém: Typ. da Livraria Gillet, 1927.

NAZZARI, Muriel. O desaparecimento do dote: mulher, famílias e mudança social em São Paulo, 1600-1900. São Paulo: Companhia das Letras, 2001 [1991].

PEREIRA, Miriam Halpern. A política portuguesa de emigração (1850-1930). Bauru/São Paulo: Editora da Universidade do Sagrado Coração (Edusc); Portugal: Instituto Camões, 2002.

SAMARA, Eni de Mesquita. O dote na sociedade paulista do século XIX: legislação e evidências. In: Anais do Museu Paulista. Tomo XXX. São Paulo: USP, 1980/1981.

TERUYA, Marisa. Trajetória sertaneja: um século de poder e dispersäo familiar na Paraíba. Tese apresentada ao Programa de Pós-Graduação em História Social da USP. São Paulo, 2002.

WEINSTEIN, Barbara. A borracha na Amazônia: expansão e decadência (1850-1920). São Paulo: Hucitec/Edusp, 1993.

\section{RESUMO}

$O$ artigo tem como objeto as famílias da elite de Belém no periodo da economia da borracha, entre os anos de 1870 a 1920. Nele se discute a configuração e transformação de suas fortunas, os contratos de dotação e a introdução de novos grupos sociais formados por uma elite mercantil ligada direta, ou indiretamente, ao negócio da borracha. Segue evidenciando as alianças matrimoniais verticais mantidas pelos proprietários de terra e gado que, pouco a pouco, foram tendo que dar lugar aos matrimônios horizontais, marcados pelo casamento com individuos de fora do grupo de parentesco, muitos deles comerciantes recém chegados à capital. Como fontes para a realização do trabalho, foram utilizados inventários, jornais e relatórios administrativos.

Palavras-chave: elite, riqueza, casamento, ciclo da borracha, Belém.

\section{ABSTRACT}

The study focuses on elite families in the City of Belem, Amazon, Brazil, during the Rubber Boom - 1870-1920. It presents a discussion on the constitution and transformation of local private wealth and dowry. The discussion also points out the introduction of new social groups, commercially linked elites who were directly or indirectly related to the rubber trade. This analysis underlines alliances construed upon vertical marriages promoted by land owners and cattle ranchers who slowly had to give way to horizontal marriages to individuals outside the family, most of them new comers to the capital, usually merchants. The sources for the research are inventories, newspapers and administrative reports. Keywords: elite, wealth, marriage, Rubber Boom, city of Belem. 